\title{
Imperata cylindrica and Moringa oleifera: Antithrombotic Effect on Pulmonary Thromboembolism in Mice
}

\author{
Fadlina Chany Saputri ${ }^{1, *}$, Arini Andriani ${ }^{2}$, Nuriza Ulul Azmi ${ }^{1}$
}

\section{Fadlina Chany Saputri ${ }^{1 * *}$, Arini} Andriani ${ }^{2}$, Nuriza Ulul Azmi ${ }^{1}$

'Department of Pharmacology, Faculty of Pharmacy, Universitas Indonesia, Kampus UI Depok, West Java, 16424, INDONESIA.

${ }^{2}$ Laboratory of Drug Development, Faculty of Pharmacy, Universitas Indonesia, Kampus UI Depok, West Java, 16424, INDONESIA.

\section{Correspondence}

\section{Fadlina Chany Saputri}

Department of Pharmacology, Faculty of

Pharmacy, Universitas Indonesia, Kampus UI Depok, West Java, 16424, INDONESIA.

E-mail: fadlina.chany@farmasi.ui.ac.id

History

- Submission Date: 19-08-2021;

- Review completed: 25-09-2021;

- Accepted Date: 04-10-2021.

DOI : 10.5530/pj.2022.14.20

Article Available online

http://www.phcogj.com/v14/i1

\section{Copyright}

(C) 2022 Phcogj.Com. This is an openaccess article distributed under the terms of the Creative Commons Attribution 4.0 International license.

\begin{abstract}
Background: Imperata cylindrica and Moringa oleifera have been used widely as a traditional medicine to treat various diseases. These plants also have some compounds that are proven in vitro for their action to reduce platelet aggregation which has a major role in thrombosis pathogenesis. Objective: This study aimed to evaluate the effect of ethanolic extracts from I. cylindrica and $M$. oleifera as an antithrombotic agent in mice. Methods: The effects of $I$. cylindrica and $M$. oleifera on the pulmonary thrombosis in vivo and bleeding time parameters were examined. The two extracts were given orally for seven days prior to thrombosis induction. Survival rate was observed by the calculation of dead or paralysed mice and bleeding time was observed on amputated mice tails. Results: I. cylindrica and M. oleifera prevented paralyse and death caused by collagen-epinephrine induced pulmonary thrombosis in mice after 7 days pre-treatment in dose-dependent manner. The mouse tail bleeding time was significantly prolonged by administration of the extract, where I. cylindrica showed the most potent. Conclusion: These results suggest that the extract of $I$. cylindrica and $M$. oleifera have a potential activity as an antithrombotic agent in vivo. Key words: Antithrombotic, Imperata cylindrica, Moringa oleifera, Survival rate, Pulmonary thromboembolism, Bleeding time.
\end{abstract}

\section{INTRODUCTION}

Platelets play an important role in thrombus formation, including platelet adhesion, activation, secretion and aggregation. ${ }^{1}$ Thrombus formation in the arterial or venous circulation can cause serious cardiovascular diseases for example atherothrombotic sicknesses, vascular blockage, myocardial and cerebral localized necrosis which can lead to death. ${ }^{2}$ According to the World Health Organization (WHO), cardiovascular diseases is the global leading cause of death in the world. ${ }^{3}$ Likewise one of the cardiovascular diseases, pulmonary embolism from the development of deep vein thrombosis (DVT) which is a cause of major mortality occurs when the thrombus breaks apart and causing occlusion pulmonary, making thrombosis to be a major health issue that needs attention. ${ }^{1}$ The prevention of platelet aggregation will prevent the formation of thrombus and thrombosis occurrence. The antiplatelet efficacy for the prevention of thrombosis is indicated by its ability to block platelet activation and aggregation. ${ }^{4}$ Aspirin as the most widely used antiplatelet has inhibition of platelet cyclooxygenase-1 (COX-1) activity, leading to reduced thrombosis occurrence and prolonged bleeding time. Resistance or variability in the response of aspirin treatment as the cause of treatment failure nowadays can be the reason to find alternative medicine to treat thrombosis especially to inhibit platelet aggregation. ${ }^{5}$

Currently, the treatment of herbal medicine is being a concern. But, antithrombotic agents from plants are still few. Imperata cylindrica and Moringa oleifera have been used widely to treat various diseases as traditional medicine. These plants also have some compounds which are proven in vitro studies to reduce platelet aggregation. $I$. cylindrica extract was shown to inhibit adenosine diphosphate (ADP) - induced platelet aggregation, thrombin and collagen in vitro. ${ }^{6} M$. oleifera inhibited platelet aggregation throughout the five minutes and showed dose-dependent prevention. ${ }^{7}$ In addition, treatment of $M$. oleifera extract in the previous study also showed a decrease platelet count in blood. ${ }^{8}$ The mechanism of action of these plants may play different roles underlying its activity as an in vitro platelet aggregation inhibitor which has potential as a new antithrombotic agent. The development of antithrombotic agents from these plants requires further study. Therefore, this study aimed to evaluate antithrombotic activity in vivo of these plants to support in vitro studies that have shown the same activity.

\section{MATERIALS AND METHODS}

\section{Chemicals}

Collagen and epinephrine were purchased from Sigma-Aldrich (United States), saline was obtained from Euro-med (Indonesia). Carboxymethylcellulose was obtained from Brataco Chemical (Indonesia) and aspirin was purchased from Sigma-Aldrich (Tokyo, Japan).

\section{Plant Materials}

The ethanolic extracts from roots of I. cylindrica and leaves of $M$. oleifera were obtained from Research Institute for Spices and Medicinal Plants, Bogor, Indonesia. The voucher specimens were deposited at botanical gardens plant conservation center (Number: B-1690/IPHx.3/KS/VI/2017).

\section{Experimental Animals}

DDY (Deutschland, Denken, and Yoken) male mice were purchased from Veterinary IPB, Bogor, 
Indonesia. All the animals were acclimatized in a room under environmentally control at least a week before starting the experiments and also have free access to food and water. This research used experimental animals which were carried out according to ethics as set by Health Research Ethics Committees, Universitas Indonesia (Ethical Approval Number: 232/UN2.F1/ETIK/2017).

\section{Total Flavonoid and Phenolic Content Determination}

Total flavonoid and phenolic determination in each extract were done by using the spectrophotometry method. Total flavonoid determination used the aluminium chloride colourimetry method by Soares et al (2015) with modification. ${ }^{9}$ Working solutions of extracts were prepared by mixing $200 \mathrm{mg}$ of the ethanol extracts with one millilitre of $0.5 \%$ $\mathrm{w} / \mathrm{v}$ hexamethylenetetramine (HMT) solution. Twenty $\mathrm{ml}$ acetone was added followed by two $\mathrm{ml}$ of $25 \% \mathrm{HCl}$ solution, then refluxed for 30 minutes and the filtrate was collected by filtering the solutions. Acetone and then ethyl acetate was added to the filtrate. Ten $\mathrm{ml}$ of working solution from the bottom layer of the resulting mixture to which was added one millilitre of $\mathrm{AlCl}_{3}(2 \%)$ in glacial acetic acid solution to obtain the final solution and then measured in Uv-Vis at $\lambda=510 \mathrm{~nm} .{ }^{10}$

Total phenolic content determination was done using FolinCiocalteau assay following the procedure of Aid et al (2015) with slight modification. ${ }^{11}$ Two $\mathrm{ml}$ of dissolved extract in $95 \%$ ethanol as sample solution was mixed with $5 \mathrm{ml}$ of aqua dest, then $0.5 \mathrm{ml}$ of the FolinCiocalteu reagent was added to sample solution and mixed well, the solution was incubated for five minutes. After that, $1 \mathrm{ml}$ of sodium carbonate $(5 \% \mathrm{w} / \mathrm{v})$ was added, and the solution was stored for one hour at room temperature. Then, the absorbance was measured at $\lambda$ $=725 \mathrm{~nm}$.

\section{Phytochemical Screening}

The presence of flavonoids and other metabolites such as alkaloid, saponin, terpenoid and glycoside were evaluated. The phytochemical screening indicated a notable presence of alkaloid, saponin, flavonoid, terpene and glycoside in both extracts, while tannin was only noticed in M. oleifera (Table 1).

\section{In vivo Antithrombotic Activity Assay}

The experiment used two parameters, survival rate and bleeding time were done separately using different groups of five animals. All animals in both assays were treated with each extract for seven days by oral gavage daily. Survival rate and bleeding time were determined in the treated mice according to the protocols described by Saputri et al (2017) with slight modification. A pulmonary thromboembolism model was carried out to evaluate the survival rate of mice, while a tail bleeding assay was used to observe the prolongation of bleeding time. ${ }^{2}$

\section{Pulmonary Thromboembolism Model}

The treatment of mice were divided into groups as follow in Table 2. Twenty four hours after the last treatment, each actively treated mice was injected with a mixture of collagen $(700 \mu \mathrm{g} / 20 \mathrm{~g} \mathrm{BW})$ and epinephrine $(42 \mu \mathrm{g} / 20 \mathrm{~g} \mathrm{BW})$ solution in the tail vein to induce pulmonary thrombosis. ${ }^{13}$ While vehicle controls were given an injection of saline solution. After 15 minutes, the paralyzed mice was observed and the number of dead mice was recorded. While the protection percentage was calculated as described by Diminno and Silver method (1983): ${ }^{12}$

[1- (number of dead or paralyzed / total number of mice) $\times 100$

\section{Tail Bleeding Assay}

The treatment of mice were divided into groups as follow in Table 3. Five hours on the last day of treatment, animals were anaesthetized with ether by inhalation route and then placed in a horizontal position.
Table 1: Phytochemical compounds identified in different extracts.

\begin{tabular}{llll} 
Metabolite & Reagent & $\begin{array}{l}\text { I. cylindrica } \\
\text { extract }\end{array}$ & $\begin{array}{l}\text { M. oleifera } \\
\text { extract }\end{array}$ \\
\hline \multirow{2}{*}{ Alkaloids } & Bourchardat & + & + \\
& Dragendorff & + & + \\
& Mayer & + & + \\
Tannins & $\mathrm{FeCl}_{3} 3 \%$ & - & + \\
Saponins & $\mathrm{NaCl}-\mathrm{Gelatin}$ & + & + \\
Flavonoids & $\mathrm{HCl} 2 \mathrm{~N}$ & + & + \\
Terpenoids & $\mathrm{Mg}+\mathrm{HCl}$ & + & + \\
Glycosides & Lieberman & + & + \\
& Bouchard & & +
\end{tabular}

Table 2: The treatments of pulmonary thromboembolism model.

\begin{tabular}{|c|c|c|c|c|}
\hline Groups & & $\begin{array}{l}\text { Number } \\
\text { of Mice } \\
\text { (n) }\end{array}$ & $\begin{array}{l}\text { Treatments } 1^{\text {st }} \text { - } \\
7^{\text {th }} \text { days }\end{array}$ & $\begin{array}{l}24 \text { hours after } \\
\text { the last day }\end{array}$ \\
\hline \multirow{5}{*}{$\begin{array}{l}\text { Imperata } \\
\text { cylindrica }\end{array}$} & Vehicle & \multirow{5}{*}{5} & $1.5 \% \mathrm{CMC}$ & $\begin{array}{l}0.9 \% \text { saline } \\
\text { injection }\end{array}$ \\
\hline & Aspirin & & $\begin{array}{l}0.208 \mathrm{mg} / 20 \mathrm{~g} \\
\text { BW }\end{array}$ & \multirow{4}{*}{$\begin{array}{l}\text { Collagen- } \\
\text { epinephrine } \\
\text { injection }\end{array}$} \\
\hline & D1 & & $2.8 \mathrm{mg} / 20 \mathrm{~g} \mathrm{BW}$ & \\
\hline & D2 & & $5.6 \mathrm{mg} / 20 \mathrm{~g} \mathrm{BW}$ & \\
\hline & D3 & & $11.2 \mathrm{mg} / 20 \mathrm{~g} \mathrm{Bw}$ & \\
\hline \multirow{5}{*}{ Moringa oleifera } & Vehicle & & $0.5 \%$ CMC & $\begin{array}{l}0.9 \% \text { saline } \\
\text { injection }\end{array}$ \\
\hline & Aspirin & 5 & $\begin{array}{l}0.208 \mathrm{mg} / 20 \mathrm{~g} \\
\text { BW }\end{array}$ & \multirow{4}{*}{$\begin{array}{l}\text { Collagen- } \\
\text { epinephrine } \\
\text { injection }\end{array}$} \\
\hline & D1 & & $2.8 \mathrm{mg} / 20 \mathrm{~g} \mathrm{BW}$ & \\
\hline & D2 & & $5.6 \mathrm{mg} / 20 \mathrm{~g} \mathrm{BW}$ & \\
\hline & D3 & & $11.2 \mathrm{mg} / 20 \mathrm{~g} \mathrm{Bw}$ & \\
\hline
\end{tabular}

Note: D1: Dose 1; D2: Dose 2; D3: Dose 3; CMC: Carboxymethylcellulose; BW: Body Weight.

Table 3: The treatments of tail bleeding assay.

\begin{tabular}{|c|c|c|c|c|}
\hline Groups & & $\begin{array}{l}\text { Number of } \\
\text { Mice (n) }\end{array}$ & $\begin{array}{l}\text { Treatments } 1^{\text {st }} \text { - } \\
7^{\text {th }} \text { days }\end{array}$ & $\begin{array}{l}5 \text { hours on the } \\
\text { last day }\end{array}$ \\
\hline \multirow{5}{*}{$\begin{array}{l}\text { Imperata } \\
\text { cylindrica }\end{array}$} & Vehicle & \multirow{5}{*}{5} & $1.5 \%$ CMC & \multirow{5}{*}{$\begin{array}{l}\text { Tail Bleeding } \\
\text { Assay }\end{array}$} \\
\hline & Aspirin & & $\begin{array}{l}0.208 \mathrm{mg} / 20 \mathrm{~g} \\
\text { BW }\end{array}$ & \\
\hline & D1 & & $2.8 \mathrm{mg} / 20 \mathrm{~g} \mathrm{BW}$ & \\
\hline & D2 & & $5.6 \mathrm{mg} / 20 \mathrm{~g} \mathrm{BW}$ & \\
\hline & D3 & & $11.2 \mathrm{mg} / 20 \mathrm{~g} \mathrm{BW}$ & \\
\hline \multirow{5}{*}{ Moringa oleifera } & Vehicle & \multirow{5}{*}{5} & $0.5 \%$ CMC & \multirow{5}{*}{$\begin{array}{l}\text { Tail Bleeding } \\
\text { Assay }\end{array}$} \\
\hline & Aspirin & & $\begin{array}{l}0.208 \mathrm{mg} / 20 \mathrm{~g} \\
\text { BW }\end{array}$ & \\
\hline & D1 & & $2.8 \mathrm{mg} / 20 \mathrm{~g} \mathrm{BW}$ & \\
\hline & D2 & & $5.6 \mathrm{mg} / 20 \mathrm{~g} \mathrm{BW}$ & \\
\hline & D3 & & $11.2 \mathrm{mg} / 20 \mathrm{~g} \mathrm{BW}$ & \\
\hline
\end{tabular}

Note: D1: Dose 1; D2: Dose 2; D3: Dose 3; CMC: Carboxymethylcellulose; BW: Body Weight.

One $\mathrm{cm}$ segment of the tail was amputated and the ends of severed tails were immediately immersed in a falcon tube filled with isotonic saline (0.9\%). Bleeding time was monitored for 20 minutes. Although the bleeding stops before 20 minutes, monitoring was still being done to detect any re-bleeding. ${ }^{14}$

\section{Data Analysis}

The bleeding time data was collected and analyzed statistically with IBM SPSS (Statistical Program for Social Science) ver. 22. To analyze 
the distribution of normality and homogeneity, data was tested by the Shapiro-Wilk and Levene. Then, Kruskal-Wallis or one way ANOVA was used to analyze the significant difference in overall data and Mann-Whitney or LSD was used to analyze the significant difference between the treatment groups. The value of $\mathrm{p}<0.05$ was considered to be statistically significant.

\section{RESULTS}

\section{Total Flavonoid and Phenolic Content Determination}

The total flavonoid and phenolic content of I. cylindrica and M. oleifera extracts can be seen in Table 4 .

\section{Survival Rate Calculation}

The survival rate was calculated and the results were obtained as in Table 5. Positive control of aspirin increased survival rate up to $100 \%$. Extracts of I. cylindrica and M. oleifera treatments increased the survival rate up to $20 \%-60 \%$.

\section{Bleeding Time Observation}

The results of bleeding time observation can be seen in Table 6 . Overall, the groups treated with the extract can prolonged bleeding time and were significantly different with the vehicle controls and did not significantly different with aspirin controls $(\mathrm{P}<0.05)$. Except for dose 3 of I. cylindrica extract, prolongation of bleeding time showed a significant difference compared with aspirin control. Figure 1 showed that all doses in both extracts significantly increased the bleeding time more than $100 \%$ compared with vehicle group.

\section{DISCUSSION}

\section{Analysis of Total Flavonoid-Phenolic and Its Antithrom- botic Effect}

The total flavonoid and phenolic content of $I$. cylindrica and $M$. oleifera extracts can be seen in Table 4 . The results showed the extracts contained flavonoid and phenolic compounds. Total flavonoid

Table 4: Total flavonoid and phenolic determination.

\begin{tabular}{lcc}
\hline Extracts & Parameter & Content $(\% \mathrm{w} / \mathrm{w})$ \\
Imperata cylindrica & Total flavonoid & 0.002 \\
& Total phenol & 1.610 \\
Moringa oleifera & Total flavonoid & 0.020 \\
& Total phenol & 5.410
\end{tabular}

Table 5: Survival rate analysis.

\begin{tabular}{lcc}
\hline Groups & & (\%) survival rate \\
& Vehicle & 0 \\
Imperata cylindrica & Aspirin & 100 \\
& D1 & 40 \\
& D2 & 40 \\
Do 3 & 60 \\
Moringa oleifera & Vehicle & 0 \\
& Aspirin & 100 \\
& D1 & 20 \\
& D2 & 40 \\
& D3 & 60
\end{tabular}

Note: Vehicle ( $0.5 \%$ CMC volume: $0.3 \mathrm{ml} / 20 \mathrm{~g} \mathrm{BW}$ ), Aspirin ( $0.208 \mathrm{mg} / 20 \mathrm{~g} \mathrm{BW}$ ), Imperata cylindrica D1 (2.8 mg/20 g BW), Imperata cylindrica D2 $(5.6 \mathrm{mg} / 20 \mathrm{~g}$ BW), Imperata cylindrica D3 (11.2 mg/20 g BW), Moringa oleifera D1 (2.8 mg/20 $\mathrm{g} \mathrm{BW}$ ), Moringa oleifera D2 (5.6 mg/20 g BW), Moringa oleifera D3 (11.2 mg/20 g BW). D1: Dose 1; D2: Dose 2; D3: Dose 3; CMC: Carboxymethylcellulose; BW: Body Weight.
Table 6: Bleeding time observation results.

\begin{tabular}{lcc}
\hline \multirow{2}{*}{ Groups } & & $\begin{array}{c}\text { Bleeding time } \\
\text { Average }(\mathrm{min}) \pm \text { SD }\end{array}$ \\
\hline \multirow{3}{*}{ Imperata cylindrica } & Vehicle & $6.37 \pm 2.14$ \\
& Aspirin & $17.06 \pm 1.63^{*}$ \\
& D1 & $18.28 \pm 2.48^{*}$ \\
D2 & $15.45 \pm 1.77^{*}$ \\
Moringa oleifera & D3 & $19.54 \pm 0.65^{* *}$ \\
& Vehicle & $6.31 \pm 1.43$ \\
& Aspirin & $16.16 \pm 3.97^{*}$ \\
& D1 & $16.44 \pm 3.09^{*}$ \\
& D2 & $17.08 \pm 2.26^{*}$ \\
& D3 & $17.11 \pm 3.07^{*}$
\end{tabular}

Note: Vehicle (0.5\% CMC volume: $0.3 \mathrm{ml} / 20 \mathrm{~g} \mathrm{BW})$, Aspirin $(0.208 \mathrm{mg} / 20 \mathrm{~g}$ BW), Imperata cylindrica D1 (2.8 mg/20 g BW), Imperata cylindrica D2 (5.6 $\mathrm{mg} / 20 \mathrm{~g} \mathrm{BW}$ ), Imperata cylindrica D3 (11.2 mg/20 g BW), Moringa oleifera D1 (2.8 mg/20 g BW), Moringa oleifera D2 (5.6 mg/20 g BW), Moringa oleifera D3 $(11.2 \mathrm{mg} / 20 \mathrm{~g} \mathrm{BW}) .{ }^{*}$ Significantly difference $\mathrm{P}<0.05$ as compared to the vehicle group. \#Significantly difference $P<0.05$ as compared to the positive control (Aspirin) group. SD: standard deviation; D1: Dose 1; D2: Dose 2; D3: Dose 3; CMC: Carboxymethylcellulose; BW: Body Weight.

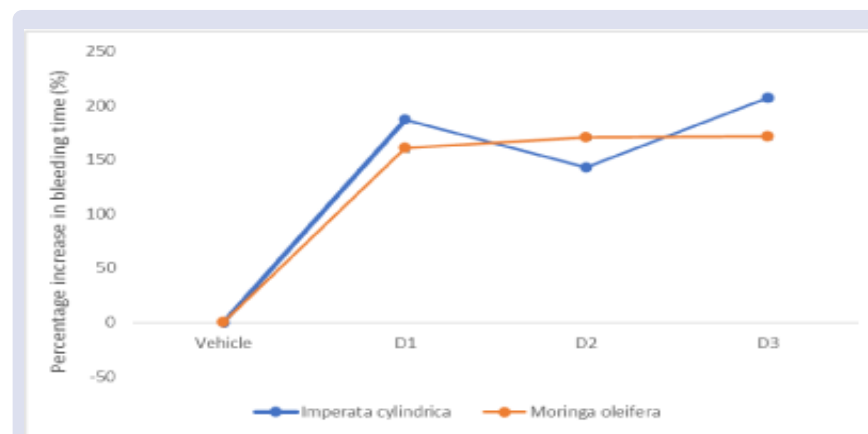

Figure 1: The percentage increase in bleeding time of Imperata cylindrica and Moringa oleifera. D1: Dose 1; D2: Dose 2; D3: Dose 3.

content was measured by $\mathrm{AlCl}_{3}$ colourimetric method. The principle involved in this method is that $\mathrm{AlCl}_{3}$ with the $\mathrm{C}-4$ keto groups or either C-3 or C-5 hydroxyl group of flavonoids structure can form acid-stable complexes. It also with the ortho dihydroxyl groups in the A- or B-ring of flavonoids will form acid-labile complexes. ${ }^{15}$ In total phenolic content used Folin-Ciocalteu method, a blue chromophore complex was formed by reaction between phosphomolybdic and phosphotungstic acid in the Folin-Ciocalteu reagent with phenolic groups in extracts. ${ }^{16}$ The presence of these compounds was assumed to have the contribution to its activity as an antithrombotic agent in vivo. In a recent study, Jantan et al (2011) has examined that platelet activity could partly be due to the total phenolic content, so it can be a potential source for cardioprotective agents. ${ }^{17}$ As well known, the phenolic compounds may reduce platelet aggregation by inhibiting Reactive Oxygen Species (ROS). In platelets, ROS are produced during platelet activation in the receptor-mediated signalling pathways. ROS induces changes in $\mathrm{Ca}^{2+}$ intracellular and may play as the second messenger on platelet activation induced by collagen or thrombin. ${ }^{18}$ The inhibitory effect of collagen-induced platelet aggregation by some flavonoids has been investigated in vitro about its ability to bind competitively with the thromboxane A2 (TXA2) receptor. ${ }^{19}$

M. oleifera has the highest total flavonoid and phenolic content, followed by I. cylindrica. However, the antithrombotic effectiveness shown by the treatment of $M$. oleifera extracts was not better than others indicating there was no association between the content of these compounds and their effectiveness as an antithrombotic agent. The assumption was because of other compounds contained in the I. cylindrica have 
a stronger potential in preventing platelet activation and aggregation thus prolonging the bleeding time and decreasing mortality due to thrombosis induced by collagen and epinephrine.

\section{Analysis of Survival Rate}

The survival rate was calculated and the results were obtained as in Table 5. Positive control of aspirin increased survival rate up to $100 \%$. Extracts of I. cylindrica and M. oleifera treatments increased the survival rate up to $20 \%-60 \%$.

Induction methods of thrombosis using collagen $(700 \mu \mathrm{g} / 20 \mathrm{~g})$ and epinephrine ( $42 \mu \mathrm{g} / 20 \mathrm{~g})$ were able to induce $100 \%$ mortality in mice. Collagen is a thrombogenic component also present in subendothelial vessels that induce platelet activation through the $\alpha 2 \beta 1$ (GPIa / IIa) receptors and glycoprotein receptor $\mathrm{VI} .{ }^{20}$ Epinephrine activates the platelets through their bonding with adrenergic $\alpha-2$ receptors. ${ }^{21}$

Calculation of survival rate showed improvement compared with vehicle control. Dose $11.2 \mathrm{mg} / 20 \mathrm{~g}$ of each extract were the optimum doses in this study which was able to increase the survival rate to $60 \%$. The effectiveness of each extract as an antithrombotic agent is assumed to be related to its ability to inhibiting the platelet aggregation of collagen-induced or other agonist-induced as already mentioned in the in vitro study. Inhibition of platelet aggregation may prevent further formation of thrombus and thrombosis occurrence.

\section{Bleeding Time Observation}

The results of bleeding time observation can be seen in Table 6 . Overall, the groups treated with the extract can prolonged bleeding time and were significantly different with the vehicle controls and did not significantly different with aspirin controls $(P<0.05)$. Except for dose 3 of I. cylindrica extract, prolongation of bleeding time showed a significant difference compared with aspirin control.

I. cylindrica prolonged the bleeding time and was statistically different from vehicle controls. The prolongation of bleeding time at dose 5.6 $\mathrm{mg} / 20 \mathrm{~g}$ is shorter than dose $2.8 \mathrm{mg} / 20 \mathrm{~g}$. The average bleeding time of I. cylindrica extract treatment in dose $11.2 \mathrm{mg} / 20 \mathrm{~g}$ showed longer bleeding time prolongation than aspirin control. Based on in vitro test, I. cylindrica showed inhibition of platelet aggregation induced by ADP, thrombin and collagen. The compounds contained in this plant had been studied and considered to be responsible for this activity. ${ }^{22}$

$M$. oleifera extract has the same effectiveness potency as antithrombotic along with aspirin in their activity to prolong the bleeding time. $M$. oleifera extract showed inhibit platelet aggregation in vitro caused by agonists such as adenosine diphosphate, collagen, and epinephrine. The inhibitory mechanism was related to its activity in inhibiting the cyclooxygenase pathway in arachidonic acid metabolism. ${ }^{23}$ However, the specific compounds which were responsible for their acts were not known certainly. $M$. oleifera contains several major bioactive compounds such as kaempferol 3-O-glucoside (astragalin), quercetin 3-O-glucoside (isoquercetin) and crypto chlorogenic acid indicating this plant has a high content of polyphenols. ${ }^{24}$ Some natural plant contents with antiplatelet activity including the phenolic groups may reduce platelet aggregation by inhibiting ROS. ${ }^{25}$

Observation of bleeding time was done to investigate the hemostatic function. Bleeding time is a measure of the primary hemostasis where platelets plugs are formed. When platelet plug formation is inhibited, the process of wound closure, as well as its time of bleeding will become longer. ${ }^{26,27}$

\section{CONCLUSION}

In conclusion, the present study revealed that extracts of Imperata cylindrica and Moringa oleifera had potential activity in preventing thrombosis. The in vivo study showed that treatment of each extract could increase the survival rate in male mice induced by collagen- epinephrine as a thrombotic agent and prolong the bleeding time with the optimum dose was $11.2 \mathrm{mg} / 20 \mathrm{~g} \mathrm{BW}$.

\section{ABBREVIATIONS}

WHO: the World Health Organization; DVT: deep vein thrombosis; COX-1: cyclooxygenase-1; ADP: adenosine diphosphate; DDY: Deutschland, Denken, and Yoken; HMT: Hexamethylenetetramine; TXA2: Thromboxane A2; CMC: Carboxymethylcellulose; BW: Body Weight; ROS: Reactive Oxygen Species.

\section{ACKNOWLEDGEMENT}

The authors would like to thank the Faculty of Pharmacy, Universitas Indonesia and Directorate of Research and Development, Universitas Indonesia for supporting this research, and Ministry of Research and Technology for financial support (PDUPT Grant: NKB-060/UN2.RST/ HKP.05.00/2021)

\section{CONFLICTS OF INTEREST}

The authors declare there is no conflicts of interest.

\section{REFERENCES}

1. Engelmann B, Massberg S. Thrombosis as an intravascular effector of innate immunity. Nat Rev Immunol. 2012;13(1):34-45.

2. Saputri FC, Nabila N, Mun'im A. Combination of Ginger and Sappan Wood Extract Effect on In vivo Antithrombotic Activity Test. J Young Pharm. 2017;9(1s):s46-8

3. Santulli G. Epidemiology of Cardiovascular Disease in the $21 \mathrm{st}$ Century: Updated Numbers and Updated Facts. J Cardiovasc Dis Res. 2013;1(1):1-2

4. Eikelboom JW, Hirsh J, Spencer FA, Baglin TP, Weitz JI. Antiplatelet drugs - Antithrombotic therapy and prevention of thrombosis, 9th ed: American College of Chest Physicians evidence-based clinical practice guidelines. Chest. 2012;141(2 SUPPL.).

5. Doutremepuich C, Aguejouf O, Desplat V, Eizayaga FX. Paradoxical Effect of Aspirin. Thrombosis. 2012;2012:1-4.

6. Moriyama H, lizuka T, Nagai M, Terazono M, Hoshi K. Antiplatelet aggregating activity of extracts of Indonesian medicinal plants I. Nat Med. 2002;56(5):178-83.

7. Rajanandh MG, Satishkumar MN, Elango K, Suresh B. Moringa oleifera Lam. A herbal medicine for hyperlipidemia: A pre-clinical report. Asian Pacific J Trop Dis. 2012;2(SUPPL2):S790-5.

8. Suzana D, Suyatna FD, Andrajati R, Sari SP, Mun A. Effect of Moringa oleifera Leaves Extract Against Hematology and Blood Biochemical Value of Patients with Iron Deficiency Anemia. J Young Pharm. 2017;9(1):79-84.

9. Soares L, Silva L, Pezzini B. Spectrophotometric determination of the total flavonoid content in Ocimum basilicum L. (Lamiaceae) leaves. Pharmacogn Mag. 2015;11(41):96.

10. Das AK, Rajkumar V, Verma AK, Swarup D. Original article Moringa oleifera leaves extract: a natural antioxidant for retarding lipid peroxidation in cooked goat meat patties. 2012;585-91.

11. Aid T, Kaljurand M, Vaher M. Analytical Methods Colorimetric determination of total phenolic microzones and digital camera. Anal Methods. 2015;7:3193-9.

12. DiMinno G, Silver MJ. Mouse antithrombotic assay: a simple method for the evaluation of antithrombotic agents in vivo. Potentiation of antithrombotic activity by ethyl alcohol. J Pharmacol Exp Ther. 1983 Apr 1;225(1):57-60.

13. Sakti AS, Nityasa AR, Saputri FC. Effect of Uncaria gambir and Uncaria sclerophylla on Pulmonary- Thromboembolism Mice. Pharmacognosy Journal. 2020;12(1):192-6. 
14. Azmi NU, Nityasa AR, Saputri FC. Antithrombotic effect of Mucuna pruriens L. and Coriandrum sativum. Pharmacog. J. 2019;11(2):413-7.

15. Bag GC, Grihanjali Devi P, Bhaigyaba T. Assessment of total flavonoid content and antioxidant activity of methanolic rhizome extract of three Hedychium species of Manipur valley. Int J Pharm Sci Rev Res. 2015;30(1):154-9.

16. Blainski, A, Lopes, GC, De Mello JC. Application and analysis of the folin ciocalteu method for the determination of the total phenolic content from Limonium brasiliense L. Molecules. 2013;18(6):685265.

17. Jantan I, Jumuddin FA, Saputri FC, Rahman K. Inhibitory effects of the extracts of Garcinia species on human low-density lipoprotein peroxidation and platelet aggregation in relation to their total phenolic contents. J Med Plants Res. 2011;5(13):2699-709

18. Olas B, Wachowicz B. Resveratrol, a phenolic antioxidant with effects on blood platelet functions. Platelets. 2005;16(5):251-60.

19. Guerrero JA, Lozano ML, Castillo J, Benavente-García O, Vicente V, Rivera J. Flavonoids inhibit platelet function through binding to the thromboxane A2 receptor. J Thromb Haemost. 2005;3(2):369-76.

20. Roberts DE, McNicol A, Bose R. Mechanism of Collagen Activation in Human Platelets. J Biol Chem. 2004:279(19):19421-30.
21. Yun-Choi HS, Park KM, Pyo MK. Epinephrine induced platelet aggregation in rat platelet-rich plasma. Thromb Res. 2000 Dec;100(6):511-8.

22. Matsunaga K, Shibuya M, Ohizumi Y. Imperanene, a novel phenolic compound with platelet aggregation inhibitory activity from Imperata cylindrica. J Nat Prod. 1995;58(1):138-9.

23. Arabshahi-Delouee S, Aalami M, Urooj A, Krishnakantha TP. Moringa oleifera leaves as an inhibitor of human platelet aggregation. Pharm Biol. 2009:47(8):734-9.

24. Vongsak B, Sithisarn P, Gritsanapan W. Simultaneous HPLC quantitative analysis of active compounds in leaves of moringa oleifera Lam. J Chromatogr Sci. 2014;52(7):641-5.

25. Olas B, Wachowicz B, Tomczak A, Erler J, Stochmal A, Oleszek W. Comparative anti-platelet and antioxidant properties of polyphenolrich extracts from: berries of Aronia melanocarpa, seeds of grape and bark of Yucca schidigera in vitro. Platelets. 2008;19(1):70-7.

26. Liu Y. Standardizing a simpler, more sensitive and accurate tail bleeding assay in mice. World J Exp Med. 2012;2(2):30

27. Adepoju GKA, Adeyemi T. Evaluation of the Effect of Lime Fruit Juice on the Anticoagulant Effect of Warfarin. J Young Pharm. 2010;2(3):269-72.

\section{GRAPHICAL ABSTRACT}

\section{GRAPHICALABSTRACT}

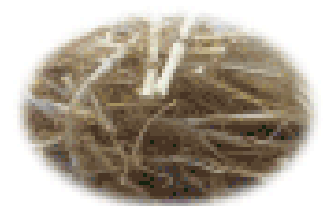

Rooks of Amperate cyindinico

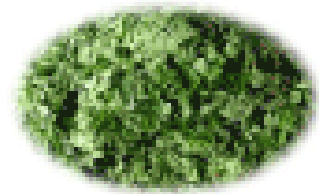

Leares of Moringe alevifero
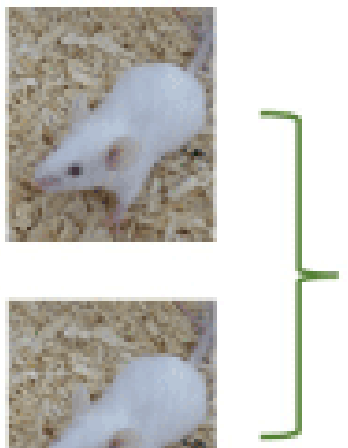

In Vivo Antithrombotic Activity Assay

Pulmonary Thromboembelism

Model

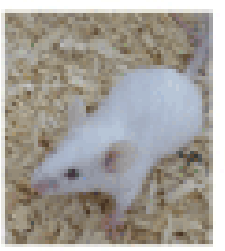

Tall Bimeding Assay
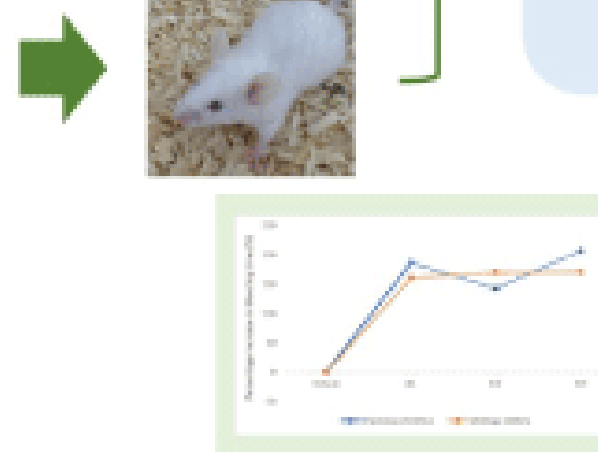

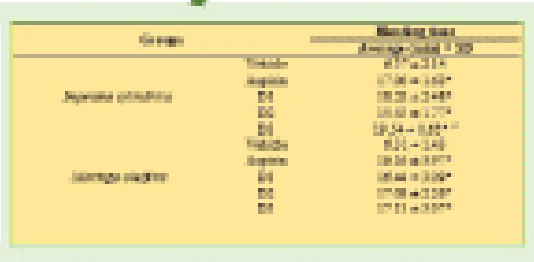




\section{ABOUT AUTHORS

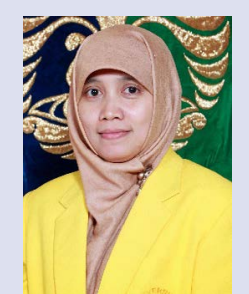 \\ Dr. Fadlina Chany Saputri., M.Si., Apt. \\ Associate Professor at Department of Pharmacology, Faculty of Pharmacy, Universitas Indonesia. She has research experience in the area of pharmacology. She is working in the development of experimental pharmacology on cardiovascular diseases and it's related risk factors based on clinical characteristics. Her research also focuses on drug discovery for CVD related to the natural product.

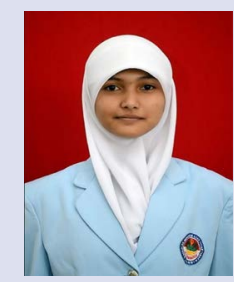 \\ Arini Andriani, S.Farm. \\ Bachelor degree at Laboratory of Pharmacology, Faculty of Pharmacy, Universitas Indonesia. Her research focus is in vivo drug discovery on the risk factor of cardiovascular disease from natural product. \\ Nuriza Ulul Azmi, M.Sc., Apt. \\ Lecturer and researcher at Department of Pharmacology, Faculty of Pharmacy, Universitas Indonesia. Her research interests are pharmacology, experimental pathology, drug discovery and development, cell chemistry, cell line, cancer, cardiovascular diseases, and natural products. She is working in the development of the animal model of various diseases and in drug discovery and development in vitro and in vivo.}

Cite this article: Saputri FC, Andriani A, Azumi NU. Imperata cylindrica and Moringa oleifera: Antithrombotic Effect on Pulmonary Thromboembolism in Mice. Pharmacogn J. 2022;14(1): 148-153. 